\title{
PLASMIDS OF PHAGE-GROUP-II STAPHYLOCOCCUS AUREUS
}

\author{
K. G. H. Dyke and W. C. Noble*
}

Microbiology Unit, Department of Biochemistry, University of Oxford, South Parks Road, Oxford OXI $3 Q U$ and * The Institute of Dermatology, St John's Hospital for Diseases of the Skin, Homerton Grove, London E9 6BX

\begin{abstract}
Summary. Most phage-Group-II Staphylococcus aureus have been shown to carry at least one plasmid. The proportion of strains that are resistant to tetracycline appears to have increased during the last 17 years. Restriction maps of several of the small plasmids isolated from Group-II strains are presented and compared with those known for staphylococcal plasmids. These small plasmids are similar to previously characterised plasmids from staphylococci of other phage groups.
\end{abstract}

\section{INTRODUCTION}

Strains of phage-Group II form a distinct subgroup within Staphylococcus aureus; for example, there are suggestions that Group-II strains are more closely related to animal staphylococci than are members of Groups I or III. They also produce a different penicillinase (Richmond, 1965). The epidermolytic-toxin plasmids of Group-II staphylococci have been studied extensively (O'Reilly et al., 1981) but much less is known about the other plasmids of Group-II staphylococci than about those of the other phage groups. This paper reports a study of plasmids carried by strains of Group-II $S$. aureus isolated from various sources during a period of about 20 years and presents restriction-enzyme maps of some individual plasmids. These plasmids are compared with those known in other staphylococci in a preliminary discussion of the spread of staphylococcal plasmids.

\section{MATERIALS AND METHODS}

Strains of $S$. aureus lysed by staphylococcal phages 3A, 3C, 55 or 71 were collected from various sources. Strains collected some time ago had been maintained freeze-dried since initial isolation. Before study of plasmids was commenced, all strains were re-typed with phages of the International Phage Typing set obtained from the Staphylococcal Reference Laboratory, Colindale, London, and antibiotic sensitivity was determined by the Kirby-Bauer method using Oxoid disks containing the following antibiotics: penicillin G 10 iu, tetracycline $30 \mu \mathrm{g}$, erythromycin $15 \mu \mathrm{g}$, clindamycin $2 \mu \mathrm{g}$, neomycin $30 \mu \mathrm{g}$ and gentamicin $10 \mu \mathrm{g}$. Resistance to cadmium ions was tested using a disk containing cadmium acetate $1.3 \mu \mathrm{g}$.

Plasmid DNA was sought initially by the method of Birnboim and Doly (1979) and agarose electrophoresis. For many of the strains and for all those that contained plasmids that were further characterised, the plasmid DNA was prepared by the method of Novick et al. (1979) which involves a caesium chloride-ethidium bromide density gradient centrifugation. Restric- 
tion-enzyme analysis was done with enzymes $A l u \mathrm{I}, D d e \mathrm{I}, E c o \mathrm{RI}, H i n c \mathrm{II}, H i n d \mathrm{II}$, Hinf I, HpaI, HpaII, MboI, PvuII, RsaI, TaqI and XbaI (Bethesda Research Laboratories); the conditions of digestion were as described by the suppliers. Digestion was performed with single enzymes and with pairs of enzymes. DNA fragments were separated on either $0.85 \%$ or $1.0 \% \mathrm{w} / \mathrm{v}$ agarose gels. Where the expected fragments were smaller than about 1 kilobase $(\mathrm{kb})$ the fragments were analysed on $5 \%$ acrylamide gels. The size of fragments was determined by including suitable standards in the gels and by use of the relationship:

$$
\log (\text { size of fragment })=\frac{1}{\text { Distance of migration }}
$$

Maps were constructed from the sizes of DNA fragments obtained from digests with single restriction enzymes and with pairs of enzymes. Analysis of the results from a series of such digests resulted in an unambiguous order for the enzyme sites.

Some strains were cured of one or more of their plasmids either by repeated subculture at $42^{\circ} \mathrm{C}$ or by growth in the presence of sodium dodecyl sulphate (SDS.) $0.002 \% \mathrm{w} / \mathrm{v}$.

\section{RESULTS}

A total of 88 isolates was examined. These were assigned to 10 groups according to their origin as shown in table I. The isolates are believed to be epidemiologically distinct except as shown in the table.

Thirty-four of the isolates failed to yield any plasmid DNA on electrophoresis of a lysate. Results for the remaining 54 are shown in tables II and III. In table II, the results of 41 isolates comprising 36 epidemiologically-independent strains are shown; in all five pairs of isolates, the plasmid content was the same. There was little relationship between the antibiotic-resistance patterns and the plasmid content except in the case of tetracycline resistance; all 13 tetracycline-resistant strains carried a $4 \cdot 2-\mathrm{kb}$ plasmid. One tetracycline-sensitive strain (I18), also contained a $4 \cdot 2-\mathrm{kb}$ plasmid. There was also correlation between resistance to cadmium ions and the presence of a 3.2-kb plasmid (data not shown).

Omitting the two isolates carrying the epidermolytic toxin-specifying plasmid and those from a single source outbreak in St John's Hospital, there were 41 independent isolates from the 1960s, 19 of which carried plasmids, and 25 independent isolates from later years, 17 of which carried plasmids. Further, only one of the 19 isolates from the 1960 s yielded more than one plasmid in contrast with 11 of the 17 from later years. Twelve of the 17 strains from later years were resistant to tetracyline whereas only one of the earlier strains was tetracycline resistant. There were differences in the carriage of plasmids related to phage type (data not shown). Fifteen independent isolates were lysed by phage 71 only; eight had no plasmids, six had a small plasmid and only one carried a plasmid $>25 \mathrm{~kb}$, but amongst 17 isolates lysed by three or more of the phages, 13 had no plasmids, three had a large plasmid only and one carried both small and large plasmids.

Table III shows the plasmids carried by staphylococci from an outbreak of infection in a skin hospital, all of which were lysed by phages $3 \mathrm{~A}$ and $3 \mathrm{C}$. Four patients were involved, one of whom, Czar, yielded variants that differed in antibiotic sensitivity from those infecting the other patients. Two further variants, J149 and $\mathrm{J} 150$, were obtained by culturing the isolate J66 in the presence of SDS. All the strains shown in table III were resistant to cadmium ions. There was a correlation between the presence of a $4 \cdot 2-\mathrm{kb}$ plasmid and resistance to tetracycline, and all the strains 


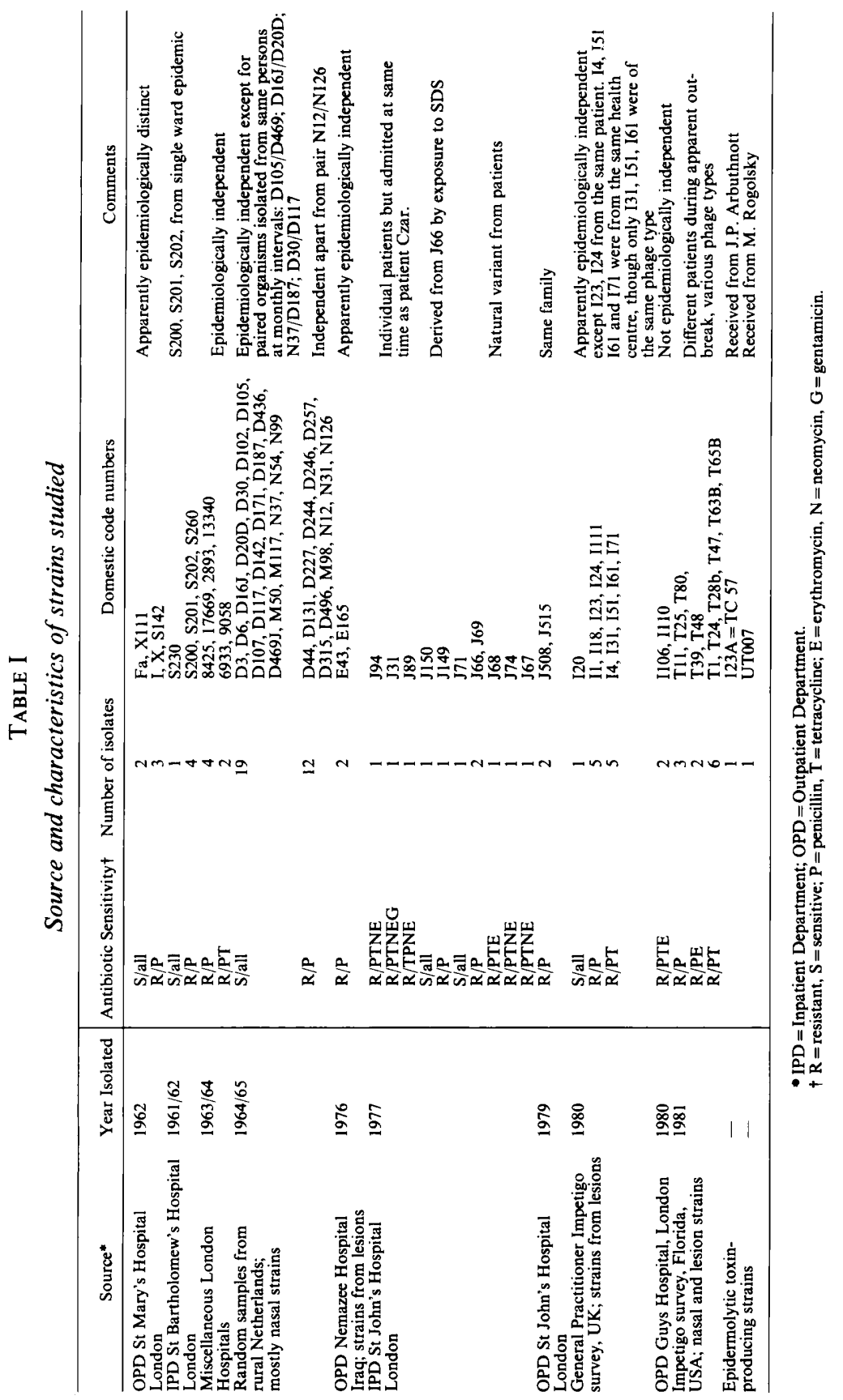




\section{TABLE II}

Characteristics of plasmids from strains of S. aureus (excluding those shown in table III)

\begin{tabular}{|c|c|c|c|c|c|c|c|c|}
\hline \multirow[b]{2}{*}{ Strain } & \multirow{2}{*}{$\begin{array}{c}\text { Date } \\
\text { isolated }\end{array}$} & \multirow{2}{*}{$\begin{array}{l}\text { Resistance } \\
\text { pattern }\end{array}$} & \multicolumn{6}{|c|}{ Presence of plasmid of size $(\mathrm{kb})$} \\
\hline & & & 1.29 & $3 \cdot 0$ & $3 \cdot 2$ & $4 \cdot 2$ & $17 \cdot 6$ & $>25$ \\
\hline $\mathrm{Fa}$ & 1962 & - & & & & & & + \\
\hline I & & $P$ & & & & & & + \\
\hline S200/201 & $1961 / 62$ & $\mathrm{P}$ & & & & & & + \\
\hline $\begin{array}{l}\mathbf{S} 230 \\
2893\end{array}$ & $\begin{array}{l}1961 / 62 \\
1963 / 64\end{array}$ & $\bar{p}$ & & & & & & + \\
\hline 9058 & $1963 / 64$ & PT & + & & + & + & & \\
\hline 17669 & $1963 / 64$ & $\mathrm{P}$ & & & & & & + \\
\hline M50 & $1964 / 65$ & - & & & & & & + \\
\hline & $1964 / 65$ & - & & & + & & & \\
\hline D30/D117 & $1964 / 65$ & - & & & + & & & \\
\hline D 102 & $1964 / 65$ & - & & & & & & + \\
\hline D 107 & $1964 / 65$ & - & & & + & & & \\
\hline D142 & $1964 / 65$ & - & & & + & & & \\
\hline D244 & $1964 / 65$ & $\mathrm{P}$ & & & & & & + \\
\hline D469 & $1964 / 65$ & - & & & & & & + \\
\hline $\mathrm{N} 12 / \mathrm{N} 126$ & $1964 / 65$ & $\mathbf{P}$ & & & & & + & \\
\hline N31 & $1964 / 65$ & $\mathrm{P}$ & & & + & & & \\
\hline N37 & $1964 / 65$ & - & & & & & & + \\
\hline N54 & $1964 / 65$ & - & & & & & & + \\
\hline J508/515 & 1979 & $\mathbf{P}$ & & & + & & & + \\
\hline & 1980 & PT & & & & + & & + \\
\hline I18 & 1980 & $\mathrm{P}$ & & & & + & & \\
\hline I31 & 1980 & PT & & & + & + & & \\
\hline I51 & 1980 & PT & & & & + & & \\
\hline I61 & 1980 & PT & + & & & + & & \\
\hline & 1980 & PT & & & & + & & \\
\hline I106/110 & 1980 & PTE & & & & + & & \\
\hline & 1981 & PT & & & & + & & + \\
\hline $\mathrm{T} 24$ & 1981 & PT & & & & + & & + \\
\hline T28B & 1981 & PT & & & & + & & + \\
\hline T39 & 1981 & $\mathrm{PE}$ & & & & & & $+t^{*}$ \\
\hline T47 & 1981 & $\mathrm{PT}$ & & & & + & & + \\
\hline & 1981 & $\mathrm{PE}$ & & + & & & & $++*$ \\
\hline T63B & 1981 & PT & & & & + & & + \\
\hline T65B & 1981 & PT & & & & + & & \\
\hline T80 & 1981 & $\mathrm{P}$ & & & & & & + \\
\hline
\end{tabular}

In addition both toxin-producing strains, $123 \mathrm{~A}$ and UT007, contained a large plasmid ( $>25 \mathrm{~kb}$ ).

* Isolates T39 and T48 carried two plasmids larger than $25 \mathrm{~Kb}$.

carried a large plasmid of $>25 \mathrm{~kb}$. In all strains there was also a small plasmid of $2 \cdot 3$ or 3.0 or $3.2 \mathrm{~kb}$. There is no obvious correlation between these small plasmids and resistance to any antibiotic.

Three of the plasmids were selected for further analysis by restriction-enzyme mapping.

1. Plasmid of $1.29 \mathrm{~kb}$. Strains 9058 (1963) and I61 (1980) both contain a very small plasmid of $1.29 \mathrm{~kb}$ in addition to a $4.2-\mathrm{kb}$ plasmid and, in the case of strain 9058 , a $3 \cdot 2-\mathrm{kb}$ plasmid. A derivative of strain 9058 , obtained after repeated subculture and growth at $42^{\circ} \mathrm{C}$, was sensitive to tetracycline and to cadmium ions but retained its resistance to penicillin. This derivative contained a single plasmid of $1.29 \mathrm{~kb}$. Similarly a tetracycline-sensitive derivative of strain I61 was obtained after repeated subculture. Because both derivatives contained only a single plasmid, a pure 
TABLE III

Plasmids in isolates from a single-source outbreak

\begin{tabular}{|c|c|c|c|c|c|c|c|}
\hline \multirow[b]{2}{*}{ Strain } & \multirow{2}{*}{$\begin{array}{c}\text { Source } \\
\text { (Patient) }\end{array}$} & \multirow{2}{*}{$\begin{array}{l}\text { Resistance* } \\
\text { pattern }\end{array}$} & \multicolumn{5}{|c|}{$\begin{array}{c}\text { Presence of a plasmid of } \\
\text { size }(\mathrm{kb})\end{array}$} \\
\hline & & & $2 \cdot 3$ & $3 \cdot 0$ & $3 \cdot 2$ & $4 \cdot 2$ & $>25$ \\
\hline J31 & Rig & PTNEG & + & & & + & + \\
\hline J89 & Eck & PTNE & & & + & + & + \\
\hline J94 & Git & PTNE & & & + & + & + \\
\hline $\mathrm{J} 67$ & Czar & PTNE & + & & & + & + \\
\hline $\mathrm{J} 74$ & Czar & PTNE & & & + & + & + \\
\hline J68 & Czar & PTE & & + & & + & + \\
\hline J66 & Czar & $\mathrm{P}$ & & + & & & + \\
\hline J69 & Czar & $\mathrm{P}$ & & + & & & + \\
\hline J71 & Czar & - & & + & & & + \\
\hline $\mathrm{J} 149$ & $\mathrm{~J} 66+\mathrm{SDS}$ & $\mathrm{P}$ & & + & & & + \\
\hline $\mathrm{J} 150$ & $\mathbf{J} 66+\operatorname{SDS}$ & - & & + & & & + \\
\hline
\end{tabular}

* $\mathrm{P}=$ penicillin, $\mathrm{T}=$ tetracycline, $\mathrm{N}=$ neomycin, $\mathrm{E}=$ erythromycin, $\mathrm{G}=$ gentamicin

preparation of the plasmid could be prepared from both. These plasmid preparations were subjected to endonuclease digestion and restriction-enzyme maps were constructed for both. The maps indicate that the two plasmids are similar but not identical (fig. 1 and see Discussion) which suggests that they were either derived from each other or from a common parent plasmid.

2. Plasmids of $3 \cdot 2 \mathrm{~kb}$. Many of the strains, particularly those from the later years,
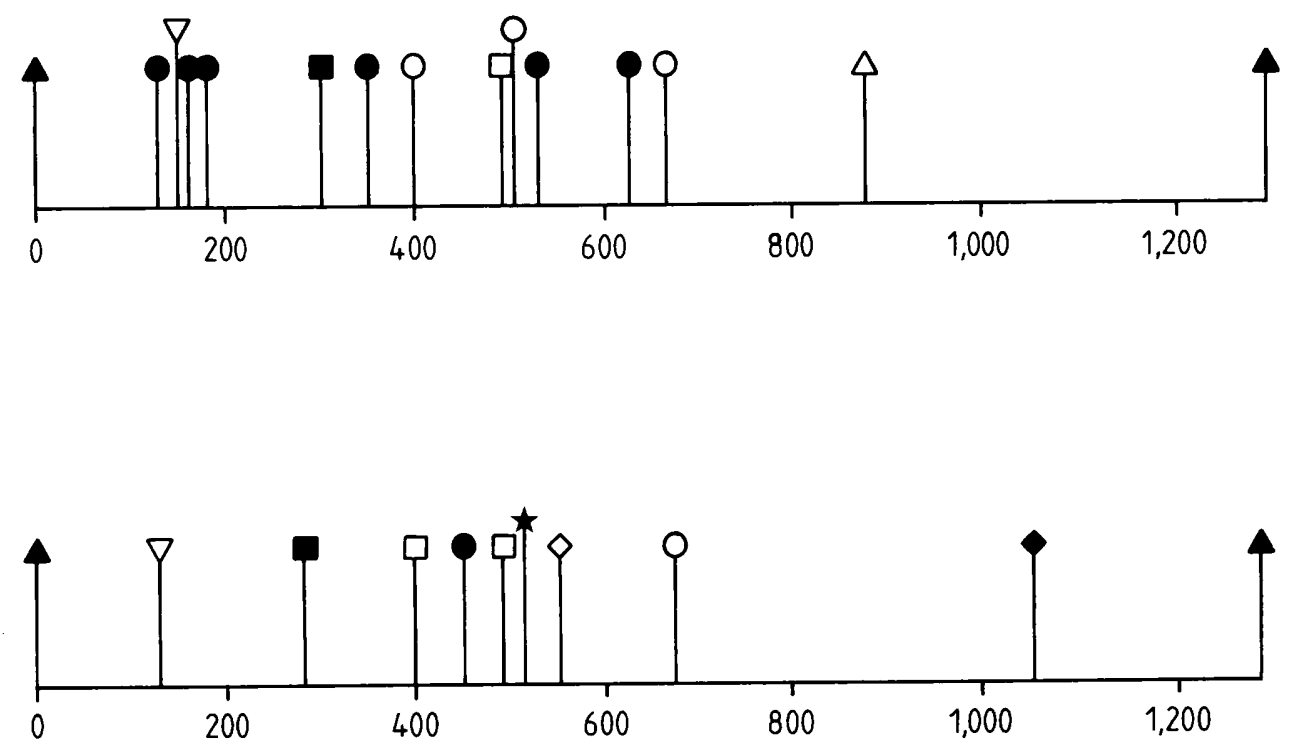

FIG. 1.-Restriction-endonuclease maps of plasmids derived from isolates I61 (top) and 9058 (bottom). Purified plasmid DNA was digested with restriction endonucleases and fragments separated on $5 \%$ polyacrylamide gels. The endonuclease sites are: $\uparrow$ HpaII, 9 AluI, $>$ MboI, $\uparrow$ TaqI, $\bigcirc$ DdeI, $\square$ RsaI, $\uparrow$ Hinf I, $\$$ HincII, $\uparrow$ HpaI, $\uparrow$ HindIII. Distances are in bases from the HpaII site. 


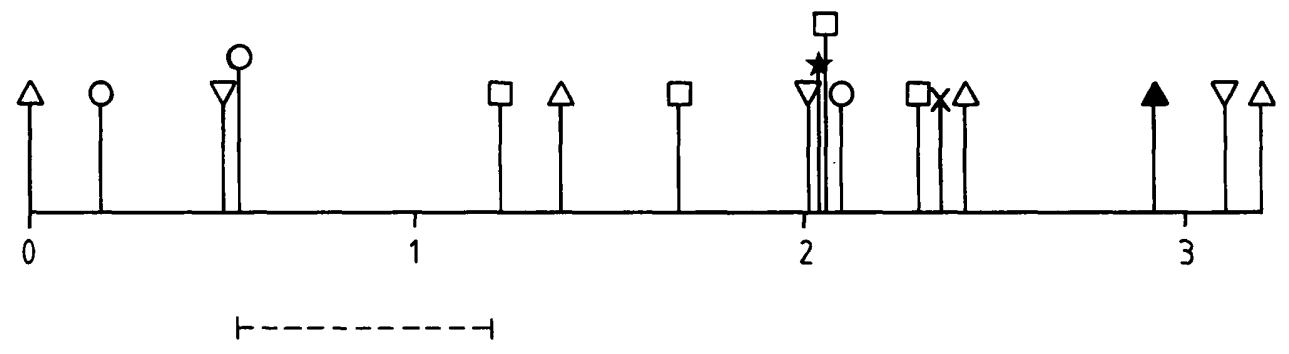

FIG. 2.--Restriction Endonuclease map of a plasmid derived from isolate D6 that confers resistance to cadmium ions. Purified plasmid DNA was digested with restriction endonucleases and fragments separated on $1.2 \% \mathrm{w} / \mathrm{v}$ agarose gels. The dotted line represents the part of the plasmid from which 80 bases are missing in a plasmid purified from isolate D107. The endonuclease sites are indicated as in fig. 1 with the addition of $x P v u I I$. Distances are given in kilobases.

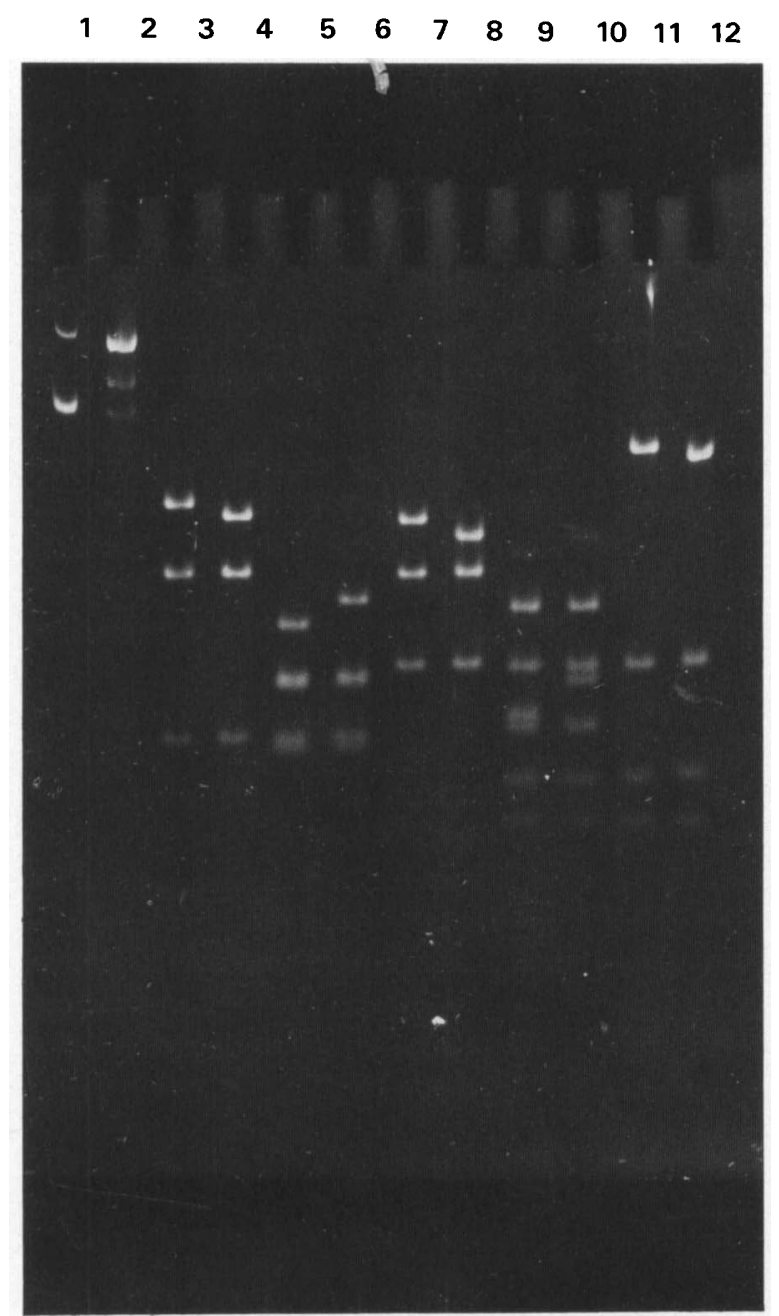

FIG. 3.-Agarose-gel electrophoresis of plasmids from strains D6 and D107 digested with MboI, HinI, RsaI and with combinations of the three enzymes. Lane 1, strain D6, undigested; 2, D107, undigested; 3, D6, MboI; 4, D107, Mbol; 5, D107, Mbo+Hinf1; 6, D6, MboI + Hinf1; 7, D6, Hinf1; 8, D107, Hinf I; 9, D107, MboI + RsaI; 10, D6, MboI + RsaI; 11, D6, RsaI; 12, D107, RsaI. 

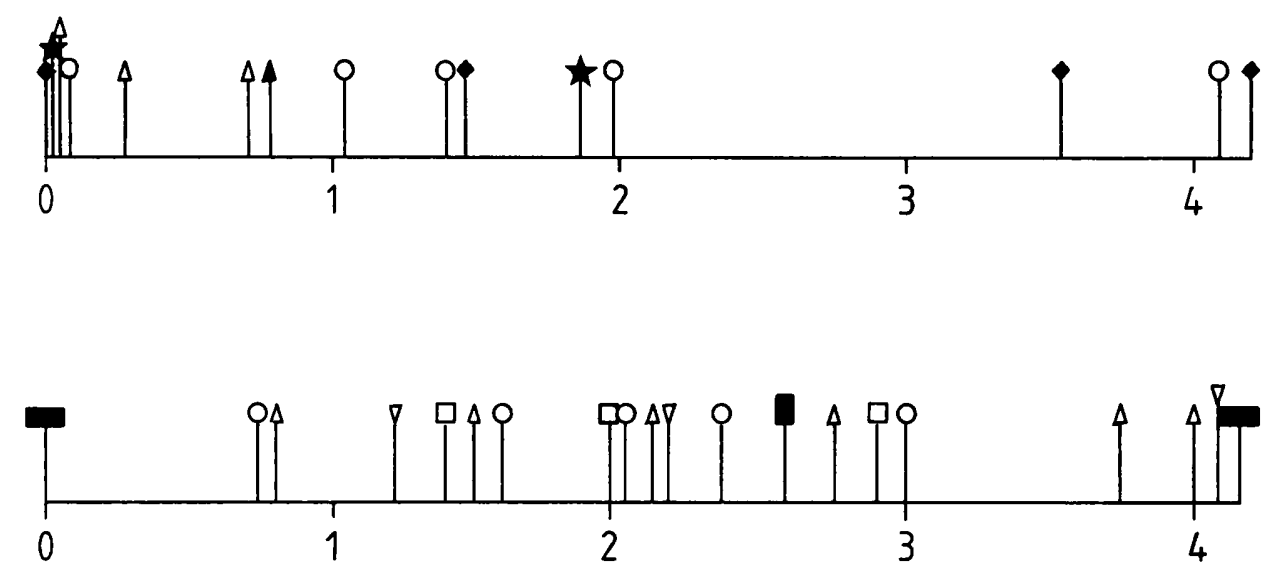

FIG. 4.-Restriction-endonuclease map of $4 \cdot 2-\mathrm{kb}$ plasmids purified from strains 151 (top) and I18 (bottom). The maps for the $4 \cdot 2-\mathrm{kb}$ plasmids from strains I61 and 9058 are undistinguishable from that of I5I. The endonuclease sites are indicated as in figs 1 and 2 with the addition of $\$ E c o$ R 1 and $9 X b a \mathrm{I}$. Distances are given in kilobases.

carried a $3 \cdot 2-\mathrm{kb}$ plasmid (table II). Derivatives that were sensitive to cadmium ions were obtained after repeated subculture at $42^{\circ} \mathrm{C}$ from isolates $9058, \mathrm{I} 31, \mathrm{D} 6, \mathrm{D} 30$ and $\mathrm{D} 107$, and in every case loss of resistance to cadmium ions correlated with loss of the 3.2-kb plasmid. Plasmid DNA was purified from strains 9058, D6, D30, D107, D117, D142 and $\mathrm{I} 31$ and a restriction-enzyme map was constructed for the plasmid from D6 (fig. 2). With the exception of that from strain D107 all these plasmids gave DNA fragment patterns, on electrophoresis after digestion by various restriction endonucleases, that were indistinguishable from each other. The plasmid from strain D107 gave patterns that indicated that it was about 80 base pairs shorter than the D6 plasmid (fig. 3) and it was possible to locate approximately the deletion on the map of the D6 plasmid (fig. 2).

3. Plasmid of $4 \cdot 2 \mathrm{~kb}$. Only one strain resistant to tetracycline was found in the 1960s group and this contained several plasmids, including one of $4 \cdot 2 \mathrm{~kb}$. Plasmid DNA was purified from isolates $\mathrm{I} 51$, I61 and from a derivative of strain 9058 that was sensitive to cadmium ions after subculture at $42^{\circ} \mathrm{C}$. In addition, plasmid DNA was purified from isolate I18 that contained a $4 \cdot 2-\mathrm{kb}$ plasmid but was sensitive to tetracycline. Restriction endonuclease mapping showed that the $4 \cdot 2-\mathrm{kb}$ plasmids from strains 9058, I51 and I61 were indistinguishable but that these plasmids bore no obvious similarity to the plasmid prepared from strain I18. Fig. 4 shows the restriction-enzyme maps and fig. 5 shows a digestion of plasmids from strains 9058, I51 and I61 with HindIII and with RsaI. In fig. 5, the $1 \cdot 29-\mathrm{kb}$ plasmids of strains I61 and cadmium-sensitive strain 9058 are also present.

\section{Discussion}

The results of the limited survey reported in this paper indicate that many Group-II strains of $S$. aureus carry plasmids and that the proportion of strains carrying more than one kind of plasmid may have increased during the last 20 years. The proportion of strains that are resistant to tetracycline has increased but it must be remembered 


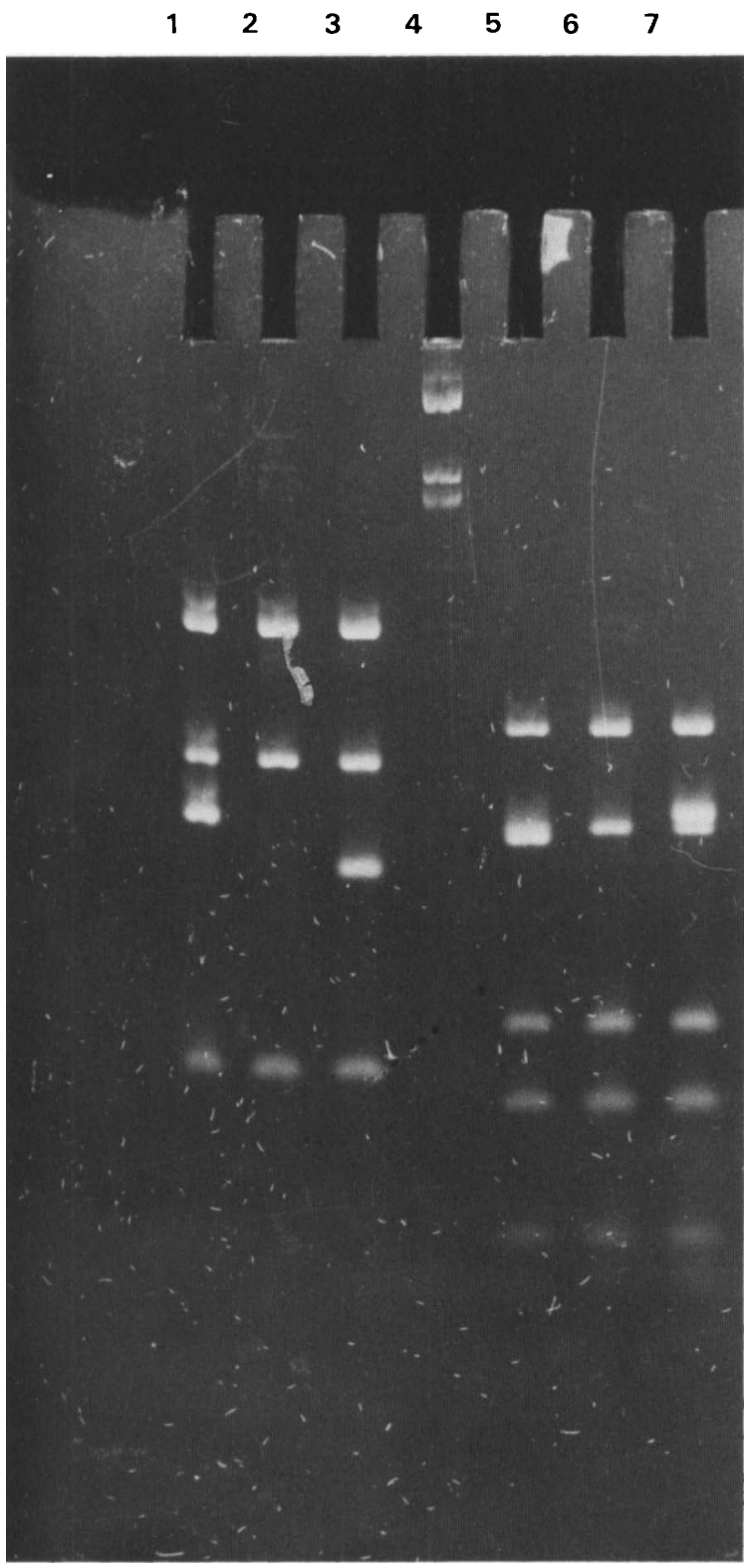

FIG. 5.-Restriction-endonuclease analysis of $4 \cdot 2-\mathrm{kb}$ plasmids from strained I $51, \mathrm{I} 61$ and a cadmium-sensitive derivative of strain 9058. Lane 1, 9058, HindIII; 2, I51, HindIII; 3, I61 HindIII; 4, I51, undigested; 5, 9058, RsaI; 6, I51, RsaI; 7, I61, RsaI. The additional bands in strains 9058 and I6I are derived from the 1.29-kb plasmid.

that, because the strains were from a number of unrelated collections, this may not be generally applicable. It is not possible to conclude much about the large plasmids because they have neither been accurately sized nor subjected to restriction-enzyme analysis but their behaviour on gels shows that they are a heterogeneous collection. The restriction analysis of the small plasmids was undertaken to obtain evidence as to 
whether or not plasmids from different isolates were similar to each other and evidence of any similarity between the plasmids of phage-Group-II staphylococci and those previously reported from other $S$. aureus strains.

The very small plasmid of $1 \cdot 29-\mathrm{kb}$ purified from strain 9058 isolated in a London Hospital in 1963 has a restriction-enzyme pattern quite similar to that of the small plasmid prepared from a strain, I61, isolated in a survey carried out in British General Practices in 1980. For example, the HpaII, MboI and TaqI sites correspond very closely for the two plasmids. One of the two RsaI sites in the 9058 plasmid is in a very similar position to that on the I61 plasmid and the single DdeI site on the 9058 plasmid corresponds to one of the three DdeI sites on the I61 plasmid.

The DNA sequence of a small staphylococcal plasmid, pSN2, has been reported by Khan and Novick (1982) and has a restriction-endonuclease pattern indistinguishable from that of the small plasmid of I61. This is remarkable because the pSN2 plasmid was obtained from a Group-I strain (DU4916) isolated in Sweden in 1969 (Dornbusch, Hallender and Lofquist, 1969). Khan and Novick (1982) reported that the pSN2 plasmid codes for a single protein of unknown function. It has also not been possible to show any function of the I61 small plasmid. Nevertheless, this small plasmid has been retained in the population of $S$. aureus and still survives after at least 11 years. As the DNA sequence of pSN2 is known and the restriction enzyme map of the related small plasmid from strain 9058, p9058-1, has been determined (fig. 1), it is possible to check whether the recognition sites for the enzymes that cut p9058-1 are present in pSN2. For all four enzymes that cut p9058-1 but do not cut pSN2, a single base change is sufficient to give the required recognition site. For example, at position 516-521 on pSN2 is a sequence ATTAAC which is at the position where HpaI cuts p9058-1. The recognition sequence for $\mathrm{HpaI}$ is GTTAAC so that a change of an A to a $\mathrm{G}$ would result in a site for $H p a \mathrm{I}$. It is concluded that p9058-1 is closely related to pSN2 and to the small plasmid and that, therefore, a variant of this small plasmid has survived in the population for at least 17 years. It will be of interest to sequence the p9058-1 plasmid to discover how many base changes have occurred and to find out whether $\mathrm{p} 9058-1$ codes for more than one protein.

The $3 \cdot 2-\mathrm{kb}$ plasmid associated wih cadmium resistance was more prevalent among the isolates from the 1960s than in those from the later years. This plasmid is much smaller than that reported by El Solh et al. (1980) but may be related to one conferring cadmium resistance in the Dornbusch et al. (1969) strain as reported by Khan and Novick (1982).

Among the strains isolated in $1964 / 65$ the $3 \cdot 2-\mathrm{kb}$ plasmid shows a variant that has lost about 80 base pairs without affecting resistance to cadmium ions or, presumably, its replication system. This is an example of a deletion, or, possibly, an insertion, occurring in the natural population. Since the $3 \cdot 2-\mathrm{kb}$ plasmid obtained from strain $\mathrm{I} 31$, isolated in 1980 , has an indistinguishable restriction-enzyme map from the $3 \cdot 2-\mathrm{kb}$ plasmid of isolates $9058(1963)$ and D6 (1964/65) it is concluded that this plasmid has survived largely unchanged in the Group-II staphylococcal population.

A $4 \cdot 2-\mathrm{kb}$ plasmid was invariably associated with resistance to tetracycline; isolate I18, which is sensitive to tetracycline, contains a similar-sized plasmid but of quite different restriction-enzyme map. The restriction-enzyme maps of three examples of tetracycline-resistance-conferring plasmids is closely related to that of pT181, a 4.4-kb plasmid (Novick et al., 1982). Similar plasmids are encountered in animal and human 
strains of $S$. aureus and $S$. epidermidis throughout the world (Khan, Carleton and Novick, 1981). Thus, the plasmid is also found in phage-Group-II isolates and has been substantially unchanged over a period of 18 years.

Resistance to erythromycin in staphylococci is sometimes associated with a small plasmid of 3728 base pairs whose sequence is known (Horinouchi and Weisblum, 1982). The isolate $T 48$ is both resistant to erythromycin and contains a plasmid of about $3.0 \mathrm{~kb}$ which has yet to be characterised. Otherwise, there is no indication of association of a particular plasmid with resistance to erythromycin in these Group-II staphylococci.

It was considered interesting to investigate the plasmids found in a single-source outbreak of infection by Group-II $S$. aureus. The isolates all carry at least two plasmids and there is no obvious correlation between antibiotic resistance and particular plasmids with the exception of the $4 \cdot 2-\mathrm{kb}$ plasmid and tetracycline resistance. Preliminary investigaion by restriction-enzyme digestions of the plasmids did not reveal any similarity between the $2 \cdot 3-\mathrm{kb}, 3 \cdot 0-\mathrm{kb}$ and $3 \cdot 2-\mathrm{kb}$ plasmids (data not given). Thus, within a single strain there is a very mobile plasmid population and because no isolate contains more than one of the three smallest plasmids, it is possible that these three plasmids are not compatible with each other. The overall picture suggests frequent transfer of plasmids between bacteria.

The expert technical assistance of Stephen Curnock is gratefully acknowledged.

\section{REFERENCES}

Birnboim H C, Doly J 1979 A rapid alkaline extraction procedure for screening recombinant plasmid DNA. Nucleic Acid Research 7:1513-1523.

Dornbusch K, Hallander H O, Lofquist F 1969 Extrachromosomal control of methicillin resistance and toxin production in Staphylococcus aureus. Journal of Bacteriology 98:351-358.

El Solh N, Fouace J M, Shalita Z, Bouanchaud D H, Novick R P Chabbert Y A 1980 Epidemiological and structural studies of Staphylococcus aureus $\mathrm{R}$ plasmids mediating resistance to tobramycin and streptogramin. Plasmid 4:171-120.

Horinouchi S, Weisblum B 1982 Nucleotide sequence and functional map of $\mathrm{pE} 194$, a plasmid that specifies inducible resistance to macrolide, lincosamide, and streptogramin type B antibiotics. Journal of Bacteriology 150:804-814.

Khan S A, Carleton S M, Novick R P 1981 Replication of plasmid pT181 DNA in vitro: Requirement for a plasmid-encoded product. Proceedings of the National Academy of Sciences, USA 78:4902-4906.

Khan S A, Novick R P 1982 Structural analysis of plasmid pSN2 in Staphylococcus aureus: No involvement in enterotoxin B production. Journal of Bacteriology 149:642-649.

Novick R P, Adler G K, Majumder S, Khan S A, Carleton S M, Rosenblum W D, Iordanescu S 1982 Coding sequence for the $\mathrm{pT} 181$ rep $\mathrm{C}$ product: a plasmid-coded protein uniquely required for replication. Proceedings of the National Academy of Sciences, USA 79:4108-4112.

Novick R P, Murphy E, Gryczan T J, Baron E, Edelman I 1979 Penicillinase plasmids of Staphylococcus aureus: restriction-deletion maps. Plasmid 2:109-129.

O'Reilly M, Dougan G, Foster T J, Arbuthnott J P 1981 Plasmids in epidermolytic strains of Staphylococcus aureus. Journal of General Microbiology 124:99-107.

Richmond M H 1965 Wild-type variants of exopenicillinase from Staphylococcus aureus. Biochemical Journal 94:584-593. 